\title{
THE DEVELOPPING TO FUTURE FRENCH TEACHERS \\ OF ETHNO-SOCIOCULTURAL COMPETENCE USING MEDIA ADVERTISING
}

\author{
ФОРМУВАННЯ У МАЙБУТНІХ ВЧИТЕЛІВ \\ ФРАНЦУЗЬКОЇ МОВИ ЕТНОСОЦІОКУЛЬТУРНОЇ \\ КОМПЕТЕНТНОСТІ НА МАТЕРІАЛІ МЕДІАРЕКЛАМИ
}

\section{Rusnak Diana ${ }^{1}$}

DOI: https://doi.org/10.30525/978-9934-571-78-7_25

Abstract. The article deals with media advertising as an authentic resource for developing to the students of ethno-sociocultural competence at the lessons of French. The ethno-sociocultural competence includes the elements of self-identification of the society such as collective representations, values, traditions, behavior, habits, rules etc. (Boyer 2011). It is considered as a main component of intercultural communicative competence of future French teachers and needs a special work in the lessons for being acquired. The purpose of article is to describe the process of acquisition of the ethnosociocultural competence at practical French lessons using media advertising as an authentic document. The article tasks are to specify components of future teachers' ethno-sociocultural competence; to describe advantages of using media advertising resources for developing this competence; to propose exercises aiming its acquisition by future French teachers. The research was conducted in context of the intercultural approach and based also on the data of sociolinguistic, sociopsychology, semiotic and theory of mass media and culture. In result of research it is specified that the ethno-sociocultural competence of future French teachers is composed of knowledge of collective representations (values, stereotypes, prejudices, symbols and myths); of sociopragmatic knowledge (behavior, habits, rules, attitudes); of sociolinguistic knowledge (proverbs, idioms, popular expressions, citations) as well as skills and abilities of using this knowledge in practice. In the class media advertising resources have advantages as

\footnotetext{
${ }^{1}$ Candidate of Pedagogical Sciences,

Associate Professor of the Department of Romance Philology and Translation,

National University Yuriy Fedkovich of Chernivtsi, Ukraine

(C) Rusnak Diana
} 


\section{Rusnak Diana}

an authentic document which could unite the learning of foreign French language and culture. In fact, media advertising is a rich source of ethnosociocultural information such as collective representations, behavior, attitudes and also proverbs, popular expressions, citations. All that accounts for studying subject in the class aiming developing of ethno-sociocultural competence. From methodical point of view, we proposed to analyze the media advertising by semiotic approach (Barthes 1963). This analysis is done by three levels: linguistic, iconic and symbolic/cultural. In the linguistic level the denotative signification of language message must be understood. This needs linguistic competence. In the iconic level a visual image must be analyzed and understood. Finally, we make the analyze of the connotation of language message or visual image in the symbolic level. This three-levels analyze could be an effective way to understand the explicit and implicit information of French media advertising and to contribute to developing of the ethno-sociocultural competence to the students.

\section{I. Вступ}

На сучасному етапі розвитку вищої освіти в Україні одним з пріоритетних виступає міжкультурний підхід до навчання іноземних мов і культур, зокрема у навчанні студентів - майбутніх вчителів/ викладачів французької мови. Це означає, що в процесі навчання французької мови і культури (ФМіК) студенти мають оволодіти міжкультурною комунікативною компетентністю (МКК), яка розглядається як здатність до спілкування між представниками різних культур, встановлюючи при цьому гармонійні стосунки у різних комунікативних ситуаціях (Г.В. Слізарова, J.-С. Beacco, М. Byram, G. Zarate).

Як зазначає М. Байрам (М. Byram), оволодіння МКК уможливлює продуктивний діалог та взаємодію між людьми, які мають різні соціальні ідентичності, зберігаючи при цьому повагу до індивідуальної особистості кожного з них [9, с. 10].

У свою чергу, Г.В. Єлізарова наголошує, що метою формування МКК є досягнення такої якості мовної особистості студента, яке дасть йому (студенту) можливість вийти за межі власної культури й набути якості медіатора культур, не втрачаючи власної культурної ідентичності [2, с. 25].

О.С. Місечко підкреслює, що міжкультурна парадигма сучасної іншомовної освіти будується на основі принципу діалогу культур, 


\section{Chapter «Pedagogical sciences»}

під яким розуміється готовність при порівнянні культурних проявів і норм у своїй та інших країнах до шанобливого сприймання різних точок зору, критичного ставлення до усталених тверджень, відкритого обміну думками на основі взаєморозуміння й поваги до культурного розмаїття $[1$, с. 65$]$.

Тому не дивно, що в останні роки спостерігається значне підвищення інтересу науковців до питань, присвячених культурному аспекту навчання іноземної мови. Так, О.Б. Бігич (2015) розглянула проблему навчання іспанської мови школярів у контексті культурологічного підходу, Л.П. Голованчук (2003) присвятила своє дослідження формуванню культурнокраїнознавчої компетентності учнів на уроках англійської мови, А.С. Іванова (2006) зосередила свою увагу на навчанні учнів старшої школи міжкультурного спілкування англійською мовою з орієнтацією на вибір професії, Н.В. Осадча (2015) описала принципи формування лінгвосоціокультурної компетентності у читанні старшокласників на уроках країнознавства, а Л.А. Сажко (2012) дослідила питання реалізація культурологічного підходу у загальноосвітньому навчальному закладі в аспекті формування полікультурної багатомовної особистості.

Велика увага дослідників присвячена формуванню у майбутніх вчителів/ викладачів іноземних мов міжкультурної комунікативної компетентності та іiї окремих складників. Зокрема, розглянуто питання розвитку лінгвосоціокультурної компетентності в аудіюванні англійською (С.П. Коржева), німецькою (А.С. Батшеєва, А.В. Козир) та фінською (С.Р. Рябова) мовами, методика формування соціокультурної компетентності засобами проектної роботи (Ю.Г. Безвін), формування естетичної культури студентів засобами художньої літератури (В. Папушина), формування соціокультурної та міжкультурної компетентності у майбутніх вчителів / викладачів на практичних заняттях (О. Березовська, I. Тригуб, Д.А. Руснак, Е.І. Шеваршинова) та у позакласній роботі (С.Г. Радул, С.О. Шехавцова). Окрема низка досліджень присвячена питанню формуванню етносоціокультурної компетентності в учнів та студентів (Н.А. Шагаева, С.П. Яковлев, Н. Boyer, M. Buchart, Ch. Marque-Pucheu).

Незважаючи на постійно зростаючий інтерес вітчизняних та зарубіжних дослідників до культурологічного аспекту навчання іноземних мов, ступінь розробки цього питання не може вважатись достат- 


\section{Rusnak Diana}

нім. Зокрема, окремого дослідження потребує питання формування у майбутніх вчителів/ викладачів етносоціокультурної компетентності (ЕСК) на практичних заняттях з французької мови. Актуальність пропонованої теми пов'язана із необхідністю підготовки висококваліфікованих фахівців, готових до міжкультурного спілкування та здатних працювати в умовах культурного різноманіття, з одного боку, та 3 недостатньою розробки методики формування ЕСК у студентів - майбутніх вчителів / викладачів на практичних заняттях з французької мови, 3 іншого боку.

Метою нашої роботи є дослідити процес формування ЕСК у майбутніх вчителів/ викладачів французької мови на матеріалі медійної реклами під час практичних занять. Для вирішення мети дослідження постають наступні завдання:

- визначити зміст ЕСК майбутніх вчителів / викладачів французької мови та місце ЕСК у структурі МКК;

- проаналізувати медіарекламу відповідно до змісту ЕСК;

- навести приклади вправ, націлених на формування ЕСК у студентів на матеріалі медіареклами.

Новизна дослідження пов'язана із тим, що вперше буде розглянуто питання навчання україномовних студентів етносоціокультурної компетентності та матеріалі франкомовної медійної реклами на практичних заняттях у закладі вищої освіти (3ВО). Практичне значення дослідження полягає у добірці франкомовної медійної реклами з етносоціокультурною домінантною та у розробленому комплексі вправ, націлених на формування у студентів ЕСК.

Дослідження виконано у контексті міжкультурного підходу до навчання іноземної мови, зокрема французької. Теоретичною основою дослідження виступають теорія міжкультурної комунікації (Ф.С. Бацевич, С.Г. Тер-Мінасова, А.П. Садохін) та теорія взаємопов'язаного навчання мови й культури (С.М. Верещагін і В.Г. Костомаров, Н.Д. Гальскова, Н.І. Гез, Г.В. Слізарова, В.В. Сафонова, Ј.-С. Веассо, М. Вyram, Ch. Puren). Разом з тим, взято до уваги результати досліджень в галузі соціолінгвістики, соціальної психології, семіотики та теорії масової комунікації і культури.

Матеріалом дослідження слугує медійна реклама (друкована та телевізійна), доступ до якої є в мережі Інтернет (сайт Culture Pub та інші). 


\section{Chapter «Pedagogical sciences»}

\section{2. Зміст формування етносоціокультурної компетентності у вчителів/викладачів французької мови}

Як зазначалось вище, міжкультурна комунікативна компетентність $\epsilon$ однією з цільових для формування у майбутніх вчителів /викладачів французької мови. Для того, щоб визначити роль і місце ЕСК у структурі МКК, розглянемо, насамперед, склад МКК студентів ЗВО, зокрема майбутніх вчителів /викладачів французької мови.

У ході своїх попередніх досліджень ми виявили, що до складу МКК входять когнітивний компонент (знання рідної та іноземної культур); прагматичний компонент (здатність спілкуватись мовою, зокрема іноземною, що включає лінгвістичну та комунікативну компетентності); афективний компонент (ставлення та поведінка людини у певних культурних ситуаціях) [5, с. 74].

3 свого боку, К. Пюрен (Ch. Puren), розглядаючи МКК як складову комплексної культурної компетентності, пов'язує ії (міжкультурну компетентність) із поняттям соціальних репрезентацій [12, с. 57]. Таку думку поділяє Г. Боуайє (Н. Boyer), який вважає, що культурна компетентність складається із різноманітних колективних репрезентацій (représentations partagées), які лежать в основі етносоціокультурної компетентності як однієї із складових колективної ідентичності суспільства. Автор зазначає, що на відміну від культури-цивілізації (або Культури з великої літери $\left.K^{\prime}\right)$, до якої входять енциклопедичні знання в галузі літератури, мистецтва, історії тощо, ЕСК складається із елементів самоідентифікації суспільства: уявлень, цінностей, поведінки, традицій, звичок, способу життя тощо, тобто всього того, що утворює менталітет народу [7, с. 336].

3 цього витікає, що ЕСК як елемент колективної свідомості суспільства, що включає в себе уявлення, традиції, цінності, переконання тощо, входить до когнітивного компоненту МКК.

Надалі, ми будемо, слідом за Г. Буайе, розрізняти поняття соціокультурної компетентності як більш загальної, яка включає енциклопедичні знання про культуру-цивілізацію, та поняття етносоціокультурної компетентності, до складу якої входять антропологічні знання про суспільство.

Таким чином, спираючись на визначення Г. Буайе [7], до змісту формування ЕСК у майбутніх вчителів / викладачів французької мови можна включити знання про колективні репрезентації французького народу (уявлення, переконання, стереотипи, упередження тощо); соиі- 


\section{Rusnak Diana}

опрагматичні знання (норми та правила поведінки, правила етикету, ритуали тощо); сочіолінгвістичні знання (ідіоматичні / сталі вирази, прислів'я, крилаті фрази, цитати тощо), а також навички та вміння застосовувати ці знання на практиці.

\section{3. Перевага використання медійної реклами} для формування у студентів етносоціокультурної компетентності

На практичних заняттях з французької мови навчання міжкультурного спілкування відбувається загалом опосередковано, через залучення у навчальний процес різноманітних автентичних матеріалів, зокрема медіa-peсурсів. Як зазначає Л. Порше (L. Porcher), медіа ресурси дозволяють розвивати у студентів критичне мислення та виступають матеріалом для обговорення соціальних, культурних, політичних та економічних проблем сучасного суспільства [11]. Отже, медійні тексти виступають багатим джерелом соціокультурної та етносоціокультурної інформації і можуть бути незамінним засобом для формування ЕСК у студентів.

Зокрема, на особливу увагу заслуговує медійна реклама, яка містить майже усі види етносоціокультурної інформації. Р. Барт (R. Bartes) визначає рекламу як засіб комунікації та як елемент масової культури, який відображає колективні репрезентації суспільства, його цінності, традиції, орієнтири та історію [6, с. 245]. А Ж. Бурбеа (G. Burbea) пояснює, що головний лемент у створенні реклами - це цільова група, кому ця реклама адресована, тобто населення, яке треба «звабити». Саме тому реклама повинна формуватися як система усталених знань, містити інформацію, яку розуміють члени суспільства для того, щоб бути для них зрозумілою і привабливою [8, с. 306].

Як ми вже зазначали у попередніх дослідженнях, реклама використовує різноманітну інформацію культурологічного характеру: прислів'я, сталі вирази, крилаті фрази; уривки пісень, віршів; назви фільмів, книг; твори мистецтва; відомих людей (співаків, акторів, спортсменів і навіть політиків); історичні особи; стереотипні репрезентації тощо [5, с. 79].

\section{1. Вивчення етносоціокультурних репрезентацій реклами}

Однією із складових змісту ЕСК виступають етносоціокультурні репрезентації, до складу яких входять колективні уявлення, стереотипи символи та міфи певного суспільства [7, с. 336]. Зокрема, у рекламі часто 


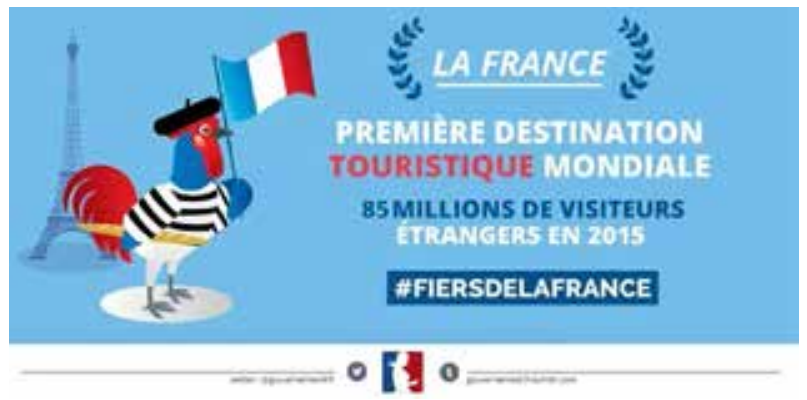

\section{Pис. 1. La France touristique}

зустрічаються символи французького суспільства: Ейфелева вежа, півень, берет, багет, смугаста футболка та синьо-біло-червоний прапор (рис. 1):

Так, Ейфелева вежа, символ Парижу та Франції, найчастіше використовується для привернення уваги до національного продукту, що ми можемо спостерігати на прикладах реклами французької авіакомпанії Air France (рис. 2), Національної лотереї (рис. 3) та відомого універмагу Galerie La Fayette (рис. 4).

Інші символи так само використовуються для наголошення на французькому походженні представлених товарів. Наприклад, чоловік у смугастій футболці на фоні кольорів французького прапору рекламує кавничку Moulinex: «Le Made in France, il y croit, on l'a testé.» (рис. 5); півень натякає на відкриття французького філіалу корейської автокомпанії Hundai: «Hundai devient HUNDAI MOTOR FRANCE. Et cela va faire de nombreux heureux! Vous.» (рис. 6); берет символізує французьке виробництво печива «TUC: Saveur chorizo, un petit plaisir olé-olé !» (рис. 7).

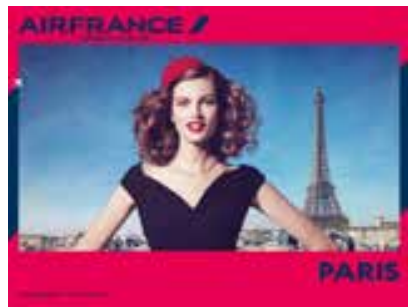

Puc. 2. Air France

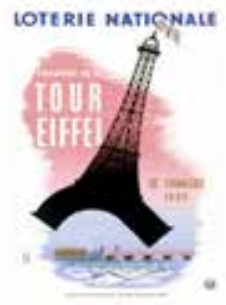

Pис. 3. Loterie Nationale

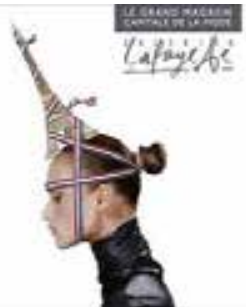

Рис. 4. Galeroe

Lafayette 


\section{Rusnak Diana}

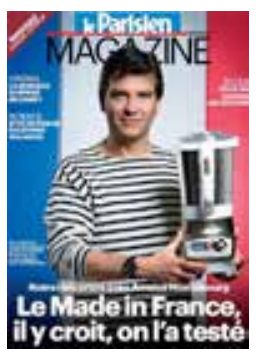

Рис. 5.

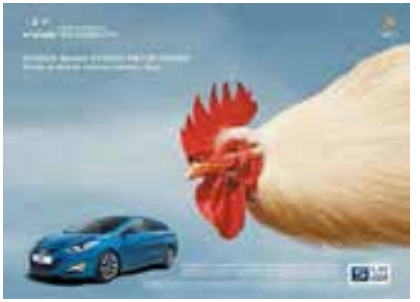

Puc. 6. Hundai Motor

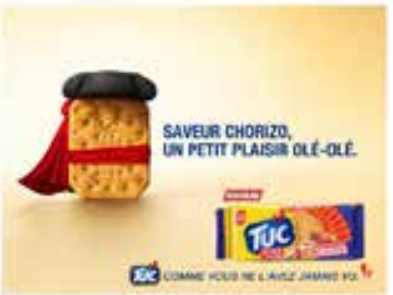

Pис. 7. Tuc LU

\section{Moulinex}

France

Серія реклам, створених $P M U$ (Оргганізація підтримки французької команди) до чемпіонату по футболу, що відбувався у Франції у 2012 році, представляє французів в образі півня, символу Франції, а команди інших країн - в образі предметів одягу, які у французів асоціюється із цією країною: Італія - капелюх від костюму Арлекіно (рис. 7: France Italie: «On n'est pas là pour jouer la comédie»), Іспанія - червона мулета тореодора (рuс. 8: France - Espagne: «Nous sommes prêts à entrer dans l'arène»), а Україна - тепла шапка у жовто-блакитник кольорах (рис. 9: France - Ukraine: «Nous serons en Ukraine comme à la maison»).

Яскравим прикладом використання авто- та гетеростереотипів $\epsilon$ відеореклама французького автомобіля Renault (https://www.youtube. com/watch?v=O_bvEoao2Ps), де Франція представлена в образі багету, Німеччина - в образі ковбаси, а Японія - в образі суші.

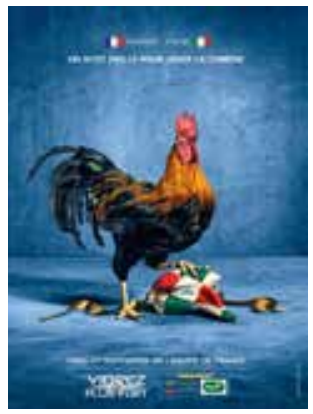

Puc. 8. France Angleterre

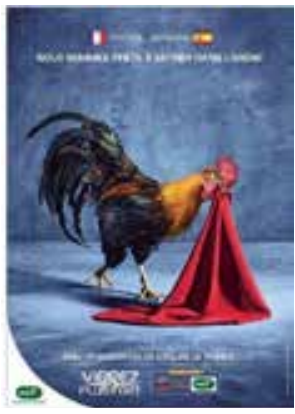

Puc. 9. France Itale

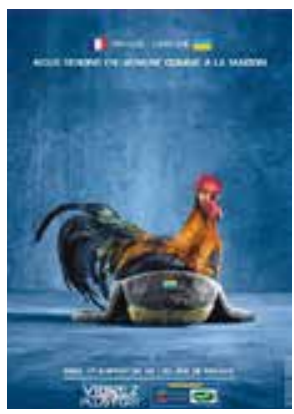

Pис. 10. France Ukraine 


\section{Chapter «Pedagogical sciences»}

3 дидактичної точки зору, опрацювання етностереотипів на практичних заняттях з французької мови дозволить студентам краще зрозуміти представників франкомовного суспільства, їхній спосіб себе ідентифікувати та їхщє бачення представників інших культур. Більш детально ми описали у своїх попередніх дослідженнях навчання майбутніх вчителів / викладачів французької мови міжкультурному спілкуванню на матеріалі різних типів стереотипів у рекламі [3; 4].

\section{2. Соціопрагматичний аспект соціальної реклами}

Наприклад, кожного року на дорогах гинуть тисячі людей, і Франція не є виключенням. Тому урядові та неурялові організації намагаються вплинути на водіїв, в тому числі і через соціальну рекламу, щоб попередити та зменщити кількість аварій, які є причиної смертності. Так, у відеороликах та рекламних афішах, створених урядовою організацією Sécurité routière, проілюстровано наслідки вживання алкоголю за кермом: «A cause de l'alcool trop de bons amis meurent sur la route. Intervenir au bon moment, c'est les aimer vivants !» (https://www.youtube. $\mathrm{com} / \mathrm{watch}$ ? $\mathrm{v}=\mathrm{hTfTkmSuoCg}$ ), «Quant on tient à quelqu'un, on le retient!» (https://www.youtube.com/watch?v=5yg4fgyZ6KM), перевищення швидкості: «Le Paradis, c'est super quand on est vieux. Roule moins vite.» (https://www.youtube.com/watch?v=sOXnmjJ2TLY), порушення правил дорожнього руху: «Vous avez juste passé à l'orange, il passera juste sa vie à l'hôpital» (рис. 11), «Vous avez juste oublié un clignotant, il est juste un peu mort» (рис. 12) та наглошено на нагальній потребі для водіїв надягати жовті жилети вночі: "C'est jaune, c'est moche, ça ne va avec rien, mais ça peut vous sauver la vie» (рис. 13).

Для посилення еффекту та впливу на цільову групу, рекламу жовтих жилетів представляє відомий французький модельєр Карл Лагерфельд (Karl Lagerfeld). До речі, реклама часто звертається до відомих людей, які мають авторитет у суспільстві, для підтримки або нав'язування певних праил поведінки або певних ідей. Наведемо декілька прикладів із серії соціальної реклами $A I D E S$ на підтримку людей, хворих на СНІД, з метою усунення дискрімінації цих осіб у суспільстві. Так, улюблений французами співак Джони Холлидей (Jonny Hallyday) питає з плакату: - Est-ce que vous aimeriez aitant ma gueule si j'étais séropositif? (рис. 14); Ніколя Саркозі (Nicolas Sarkozy), діючий на той час президент, цікавиться: - Voteriez-vous pour moi, si j'étais séropositif? 


\section{Rusnak Diana}

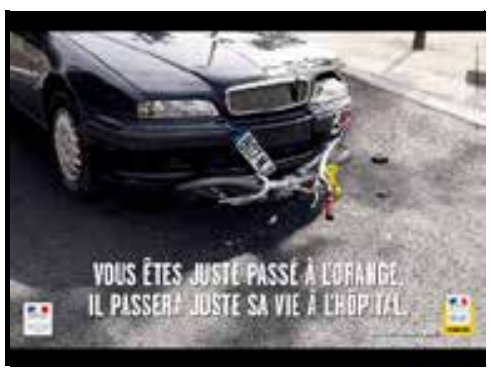

Рис. 11. Sécurité routière

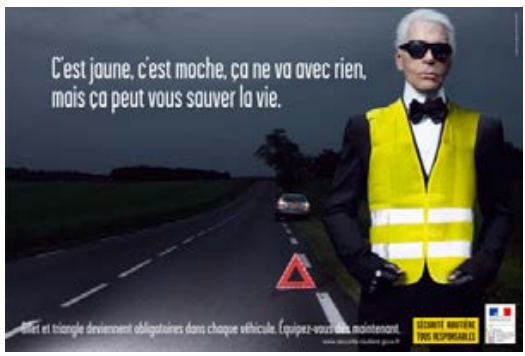

Рис. 13. Sécurité routière

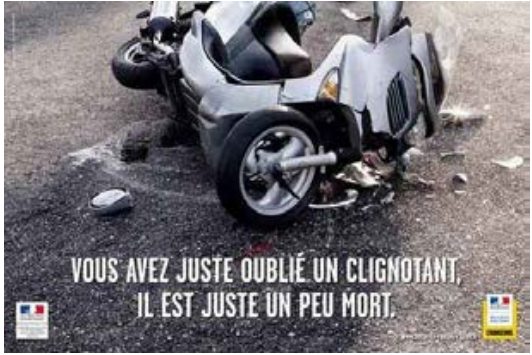

12. Sécurité routière

(рис. 15) - Est-ce que me trouveriez aussi drôle si j'étais séropositive?, теж запитує французька комедійна акторка Мюріель Робін (Muriel Robin) (рис. 16). I на кожному плакаті фраза C'est le SIDA qu'il faut exclure, pas les séropositifs! звучить відповідддю на поставлені питання.

Змінити у суспільстві ставлення до безпритульних за допомогою відомих брендів зробила спробу благодійна організація Аврора (Aurore). Вона запустила у соціальні мережі три рекламні афіші, що нагадують рекламу відомих французьких брендів високої моди. Так, на фоні образів безпритульних Yves-Saint

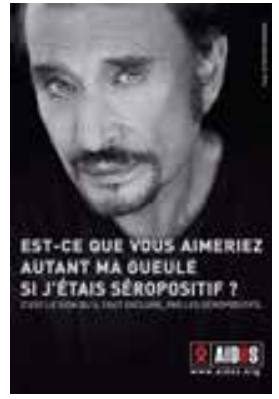

Puc. 14. AIDES

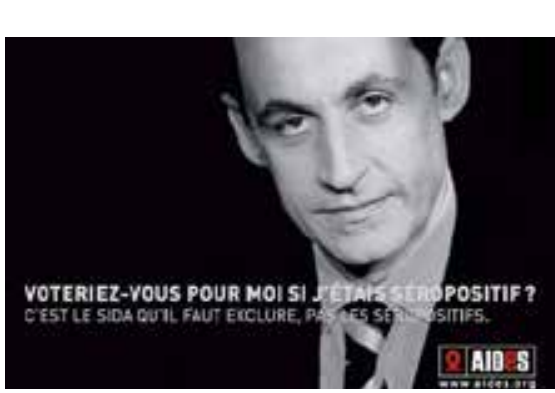

Рис. 15. AIDES

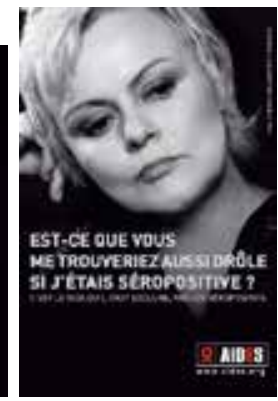

Puc. 16. AIDES 


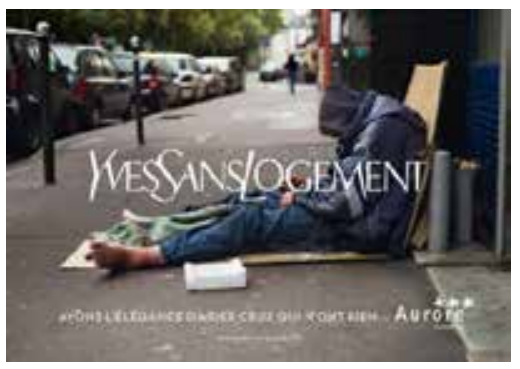

Pис. 17. Aurore

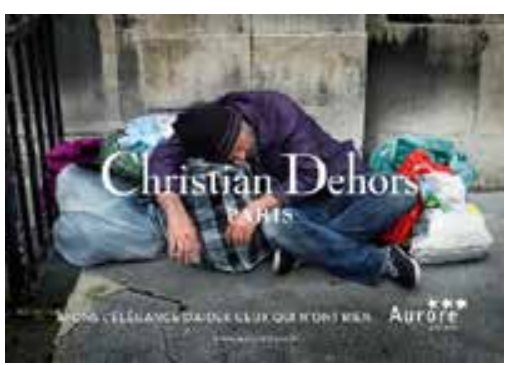

Pис. 18. Aurore

Laurent став Yves-Sans Logement (рис. 17), Christian Dior перетворився на Chrisrian Dehors (рис. 18), a Jean-Paul Gautier став Jean-Paul Galère (рис. 19). Закликом про допомогу виступає слоган, один на трьох плакатах: Ayons l'élégance d'aider ceux qui n'ont rien! (Association Aurore).

Отже, як ми бачимо, соціальна

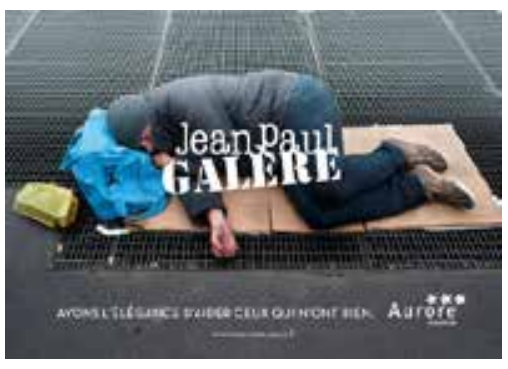

Рис. 19. Aurore реклама використовує різноманітні засоби (вербальні та невербальні) впливу на громадян з метою змінити їхню поведінку чи ставлення до соціальних явищ.

3 педагогічної точки зору, використання такого типу реклами на практичних заняттях з французької мови не тільки надасть студентам соціопрагматичних знань про використання вербальних та невербальних засобів впливу на норми поведінки та ставлення до певних проблем у франкомовному суспільстві, а ще й матиме виховний ефект та сприятиме розвитку у них (студентів) критичного мислення.

\section{3. Соціолінгвістичний компонент франкомовної реклами}

Як вже зазначалось вище, рекламні слогани часто використовують прислів'я, сталі вирази, цитати із літературних творів, пісень, фільмів тощо.

Наприклад, щоб привернути увагу до проблем безпритульних, благодійна організація la Fondation Abbaye Pierre використала у своїй рекламі слоган «Métro - boulot - métro» (рис. 20), який нагадує відомий 


\section{Rusnak Diana}

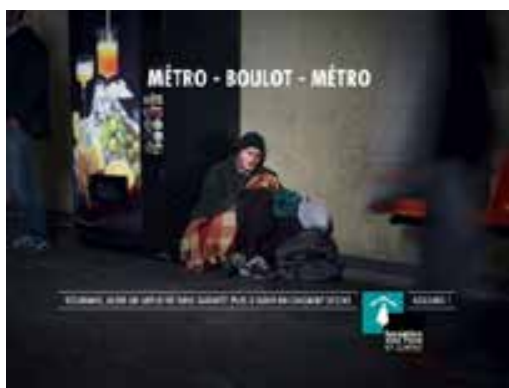

Pис. 20. La Fondation Abbaye Pierre

вираз «Métro, boulot, dod». Запозичена 3 віршу Пьєра Беама (Pierre Béam), ця фраза характеризує щоденний монотонний ритм жителів міста, зокрема парижан. «Métro» це дорога на метро вранці, «boulot» означає робочий день, а «dodo»повернення додому і сон. Замінивши dodo на métro (Métro - boulot métro), автори наголошують на тому, що у безпритульних немає житла і їм немає куди повертатися спати.

Слоган урядової кампанії Alimentation проти марнотратства харчів "Qui jette un oeuf, jette un boeuf» (рис. 21) наслідує відоме прислів'я "Qui vole un oeuf vole un boeuf», який означає, що вкравши якусь дрібницю, ти можеш вкрасти щось більш цінне. А слоган «Arrêtez vos salades» (рис. 22), організації із захисту довкілля France Nature Environnement, натякає на сталий вираз «raconter des salades», який має значення «брехати / розповідати неправдиві історії»:

Реклама використовує розповсюджені у суспільстві лексичні одиниці для того, щоб стати ближчою до споживача та легко йому запам'ятатись [7]. Прислів'я, сталі вирази або цитати із літературних творів утворюють прецедентну лексику, яка є зрозумілою всім члена суспільства на імпліцитному рівні і саме тому вона (прецедентна лек-

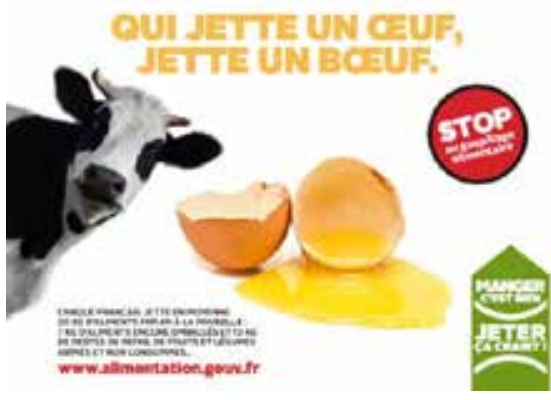

Рис. 21. Alimentation

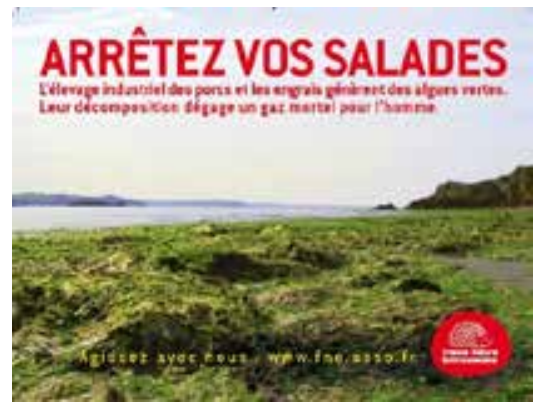

Puc. 22. France Nature Environnement 
сика) входить до складу ЕСК. Очевидно, що реклама, в якій вживається така лексика, дозволяе опрацювати на практичних заняттях соціолінгвістичний аспект ЕСК.

\section{4. Дидактичний аспект використання медійної реклами на практичних заняттях $з$ французької мови}

Виходячи із вищевикладеного, ми зустрічаємо у рекламних матеріалах різноманітну етносоціокультурну інформацію, яка виступає предметом вивчення в процесі формування ЕСК у студентів на практичних заняттях з французької мови.

Для того, щоб забезпечити розуміння студентами імпліцитної інформації реклами, ми пропонуємо застосувати семіотичний підхід до аналізу рекламних повідомлень [5, с. 79]. Згідно з цим підходом, аналіз має відбуватися на трьох рівнях: лінгвістичному, іконічному та символічному (або культурному).

На лінгвістичному рівні відбувається аналіз мовного повідомлення, його денотативного значення. Тут важливою $є$ лінгвістична компетентність студентів. Так, щоб перевірити розуміння студентами слогану будь-якої реклами у прямому значенні, можна застосувати різні стратегії, серед яких дослівний переклад. Наприклад:

- Lisez et traduisez le slogan de la publicité.

Інтерпретація значення мовного повідомлення відбувається на символічному рівні (див. нижче).

На іконічному рівні відбувається аналіз іконічного зображення (для рекламних афіш) або аналіз відеоряду (для рекламних роликів). На цьому рівні також відбувається розшифрування денотативного значення візуальних образів, для чого застосовується стратегія загального розуміння рекламних образів. Студентам пропонується відповісти на питання типу:

- Qui voyez-vous sur l'image? Quels objets sont représentés? Comment est la personne vue? etc.(для іконографічної реклами);

- Qui voyez-vous sur l'écran? Quels sont les objets présentés? Que font les personnages de la vidéo? еtc. (для відеролику).

На символічному / культурному рівні проводиться аналіз конотативного значення візуальних образів або мовного повідомлення. На цьому рівні застосовуються стратегії детального розуміння та розшифрування імпліцитного значення тексту. Студенти мають відповісти на питання: 


\section{Rusnak Diana}

- A quoi cette image fait-elle allusion? A quel phénomène culturel cette image fait-elle référence? Etc.

- A quoi fait référence le slogan? Que le slogan vous rappelle-t-il? Quelle expression connue se cache dans le slogan de la publicité? etc.

\section{1. Вправи для опрацювання етностереотипів у рекламі}

Наведемо приклад методичної розробки на основі відеореклами Acadomia, організації з підтримки учнів на дому. Acadomia робить акцент на індивідуальних здібностях кожної дитини, що показано на їхній рекламній афіші (рис. 23), де зображено дитину, друга половина якої нагадує Альбера Ейнштейна, загальновідомого своєю геніальністю, а слоган каже: On croit au potentiel de chaque enfant!

У відеоролику цієї організації (https://docs.google.com/forms/d/1v8WuL6zOL8ZX1FwOBsPwaCAWnPezk-EQg1gJK312EY/edi) використано образ жаби, яка ні на що не здібна, проте заслужила найбільших похвал як блюдо на обід. Наголошуючи на індивідуальності кожної дитини, у цій рекламі використано стереотиповане уявлення про французів-жабоїдів (англійці, наприклад, називають французів Frog із-за того, що вони їдять жаб).

Для розуміння цього відео на лінгвістичному та візуальному рівнях ми пропонуємо студентам відповісти на таки питання (з метою розкриття денотативного значення відеоролику):

Для розуміння відеоролику на символічному / культурному рівні ми пропонуємо студентам відповісти на наступні питання (з метою розкрити конотативне значення рекламного повідомлення) (додаток 1).

\section{- Régardez une deuxième fois la vidéo et répondez:}

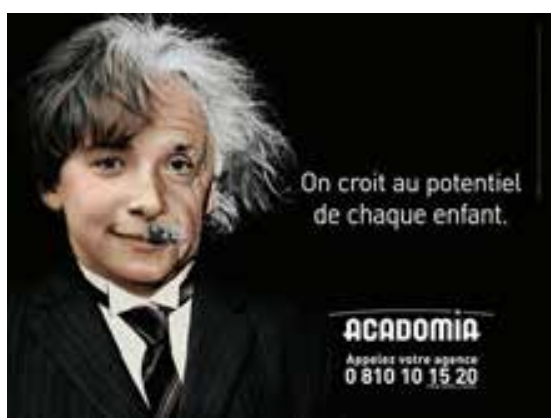

Puc. 23. Acadomia

1. Quelle idée est suggérée par la vidéo?

2. Quel stéréotype sur les Français est mis en situation dans la vidéo?

Щоб полегшити завдання студентам, можна запропонувати варіанти відповідей, наприклад:

6. Quelle idée est suggérée par la vidéo?

a) Les grenouilles sont bonnes à manger. 


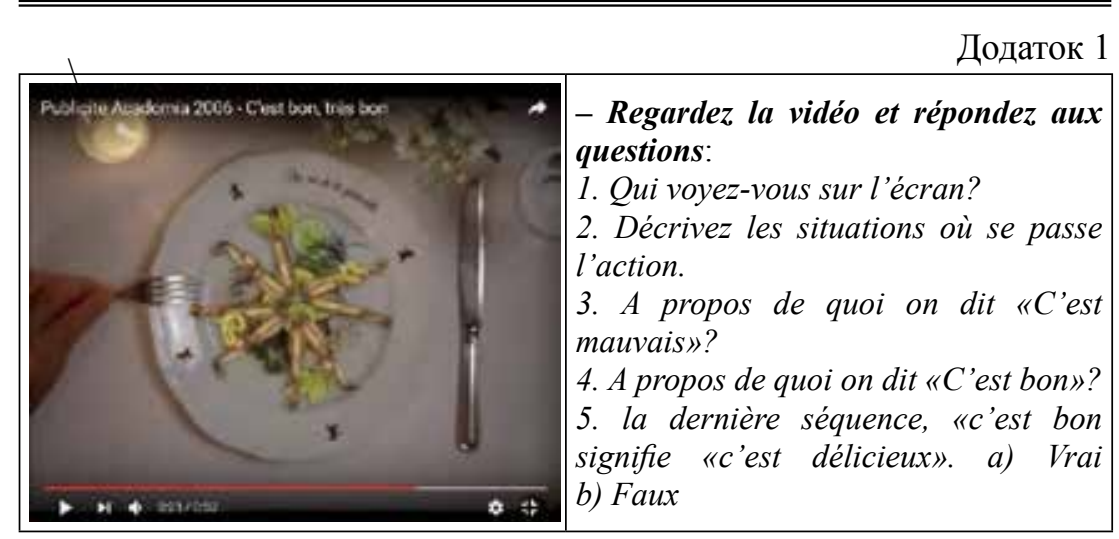

b) Les enfnats ne sont pas bons à rien.

c) Chaque enfant est différent, il a ses particularités personnelles.

7. Quel stéréotype sur les Français est mis en situation dans la vidéo?

a) Les Français sont intelligents.

b) Les Français aiment manger des grenouilles.

c) Les Français sont râleurs.

В контексті міжкультурного підходу, на наступному етапі можна запропонувати студентам переглянути українську рекламу, де використано подібне явище, зокрема етностереотипи, порівняти дві реклами, дати свою оцінку та скласти свій варіант реклами, який би представив їхнє особисте бачення українського народу. Наприклад, реклама Мезиму (https://www.youtube.com/watch?v=19QdCmnB95Y) робить акцент на гостинності українців та звичці накривати багатий стіл для зустрічі гостей:

8) - Regardez la publicité ukrainienne et repérez le stéréotype sur les Ukrainiens qui est mis en situation.

9) - Imaginez une publicité d'un produit à votre choix qui mettrait en situation quelques images stéréotypées sur des Ukrainiens.

\section{2. Вправи на опрацювання соціолінгвістичного та соціопрагматичного компонентів ЕСК у рекламі}

Для розуміння соціолінгвістичної та соціопрагматичної інформації у рекламі застосовуються також стратегії загального та детального розуміння. Наприклад, для розуміння соціальної реклами проти марнотратства харчів Alimentation на етапі загального розуміння пропонується таке завдання: 


\section{Rusnak Diana}

Додаток 2

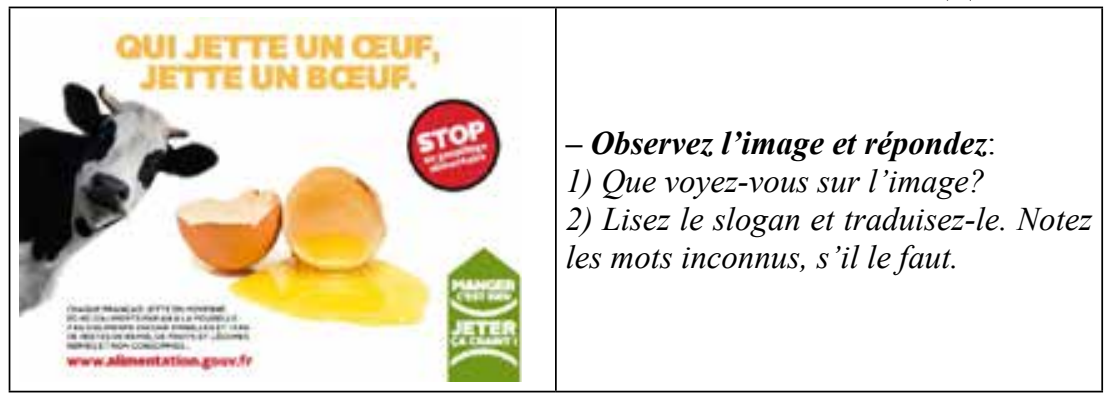

На етапі детального розуміння $з$ метою декодування імпліцитної інформації, пропонуємо студентам наступне завдання:

1) Connaissez-vous les proverbes français? Trouvez celle qui se cache dans le slogan.

2) Comment comprenez-vous le sens du proverbe?

3) Quel sens du proverbe est associé à l'image de la publicité?

4) Quels autres moyens sont exploités dans cette publicité pour faire arrêter le gaspillage des produits alimentaires?

За такою ж схемою пропонуємо вправи для опрацювання соціальної реклами France Nature Environnement:

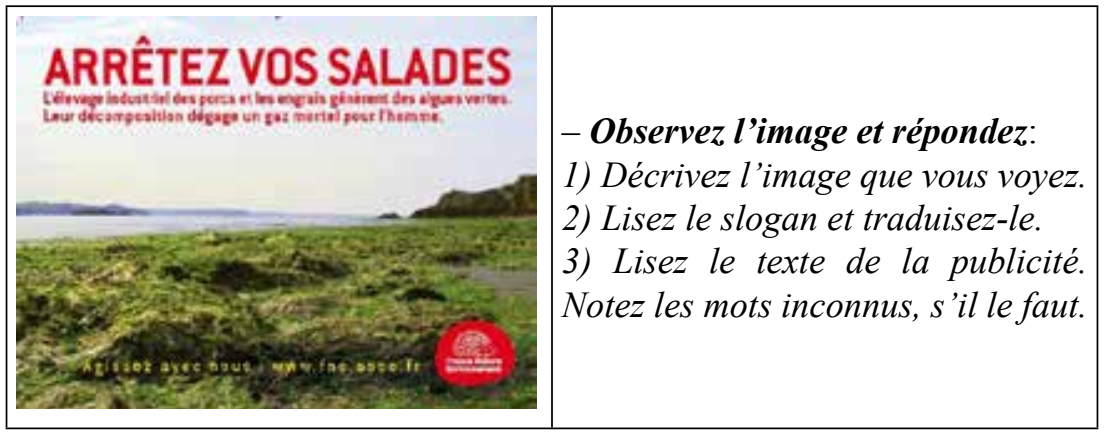

A quelle expression figée fait référence le slogan?
a) Raconter des salades
b) Manger de la salade
c) Arrêter de manger 


\section{Chapter «Pedagogical sciences»}

10) Que signifie, à votre avis, «des salades» dans cette expression? Choisissez la bonne réponse:

a) des repas sains

b) des histoires longues

c) des histoires peu crédibles, des mensonges

11) Expliquez le sens du slogan "Arrêtez vos salades» dans le contexte de cette publicité. De quel problème social s'agit-il?

Після того, як студенти зрозуміють подану інформацію, необхідно їм запропонувати завдання на порівняння подібних явищ у рідній культурі, а також завдання у створенні власних повідомлень із етносоціокультурним змістом.

- Trouvez une publicité ukrainienne qui exploite un proverbe ou une expression figée. Traduisez-la en français. Expliquez son sens.

- Imaginez le slogan pour une publicité sociétale ukrainienne en employant une citation ou une expression figée. Quels moyens utiliseriezvous pour produire un effet désirable sur le public cible de votre publicité?

Для того, щоб проаналізувати вербальні та невербальні засоби впливу на цільову групу, пропонуємо опрацювати серію реклами $A I D E S$ на підтримку хворих на СНIД (рис. 14, рис. 15, рис. 16). На етапі загального розуміння даємо студентам завдання упізнати спочатку людей, зображених на афішах:

\section{Observez les images et répondez:}

1) Qui voyez-vous sur les images? Les connaissez-vous?

2) Associez les noms des gens vus avec leurs photos:

a) François Sarkozy b) Muriel Robin c) Jonny Hallyday

Потім пропонується проаналізувати лінгвістичне повідомлення кожної афіші:

\section{Lisez les slogans et dites:}

3) Quel est le sens explicite de chaque phrase?

4) Quelle structure grammaticale est employée et quel acte de parole exprime-t-elle?

Для більш детального розуміння пропонуємо проаналізувати, кому адресована така реклама і який ефект вона має на цих людей:

5) Quel est le public cible de chaque affiche?

6) A quelles fins les gens connus sont-ils exploités dans la publicité?

7) Quel effet ces images doivent-elles avoir sur les gens?

8) Pourquoi emploie-t-on des phrases hypothétiques? Quel est leur rôle? 


\section{Rusnak Diana}

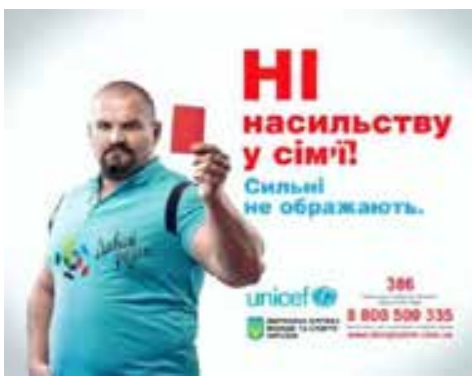

Pис. 24. Unicef
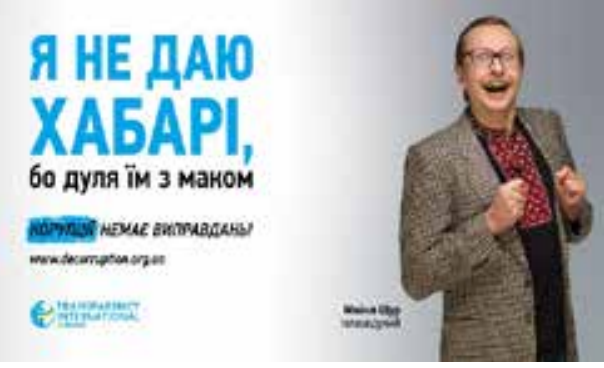

Рис. 25. Transparancy Internatinal

Для порівняння з подібним феноменом у власній культурі, можна запропонувати студентам пригадати відомих людей в українській рекламі та їхній вплив на споживачів. Інший варіант: підібрати соціальні реклами, в який знімаються відомі українці, та обговорити їх. Наприклад, відомий український спортсмен Василій Вірастюк, що має титул «Найсильніший чоловік у світі», задіяний у рекламі Unicef проти насильства у сім’і, бо «сильні не ображають» (рис. 24), а телеведучий Майкл Щур «не дає хабарів» у соціальній рекламі проти корупції Transparency Internatinal (рис. 25).

\section{5. Висновки}

Підсумовуючи, зазначимо, що реклама виступає ідеальним засобом для поєднання навчання мови та культури на практичних заняттях 3 французької мови. Як автентичний матеріал, багатий на етносоціокультурну інформацію, вона дозволяє ознайомитись із репрезентації та уявлення народу, мова якого вивчається, з його звичками та способом життя, ілюструє прецеденту лексику.

Проаналізовані рекламні матеріали показують, що соціопрагматичний компонент ЕСК найбільш яскраво виражений у соціальній рекламі, яка використовує різноманітні засоби впливу на цільову групу відповідно до своєї мети - змінити або вплинути на поведінку та звички представників певного суспільства.

3 методичної точки зору, формування ЕСК у студентів на матеріалі реклами відбувається на трьох рівнях: лінгвістичному, іконічному та символічному. Такий підхід має забезпечити комплексне розуміння експліцитної та імпліцитної інформації реклами, тим самим сприяти 


\section{Chapter «Pedagogical sciences»}

формуванню ЕСК у студентів та створити передумови для формування МКК як цільової для майбутніх вчителів / викладачів французької мови.

Перспективи подальших розвідок передбачають урізноманітнення типів і видів автентичних медіа-ресурсів та розроблення методичних рекомендацій щодо їх використання в процесі формування у студентів ЕСК на практичних заняттях з французької мови.

\section{Список літератури:}

1. Місечко О. Є. Міжкультурна парадигма іншомовної освіти: що криється в деталях? / О. Є. Місечко // Науковий вісник Київського національного лінгвістичного університету. Серія Педагогіка та психологія. - Вип. 29. - Київ: Видавничий центр КНЛУ, 2018. - С. 62-71.

2. Елизарова Г. В. Формирование межкультурной компетенции студентов в процессе обучения иноязычному общению: Дис. ... докт. пед. наук: 13.00.02. / Елизарова Г.В. - СПб., 2001. - 371 с.

3. Руснак Д. А. Мобільний кейс «Реклама як засіб формування міжкультурної компетентності: гендерні, вікові й етнічні стереотипи» для майбутніх учителів/ викладачів французької мови) // Кейсова і подкаст технології формування міжкультурної компетентності: Колективна монографія / Бігич О. Б., Руснак Д. А./ за заг. і наук. ред. Бігич О. Б. - К.: Вид. центр КНЛУ, 2017. - С. 22-91.

4. Rusnak D. A. Les contenus spécifiques de l'enseignement interculturel de futurs enseignats de FLE: stéréotypes de genre / Д. А. Руснак // Науковий вісник Київського національного лінгвістичного університету. Серія Педагогіка та психологія. - Вип. 28. - Київ: Видавничий центр КНЛУ, 2018. - С. 133-139.

5. Rusnak D. A. Exploiter la dimension culturelle de la publicité iconique pour l'enseignement interculturel des futurs enseignants de FLE / Д. А. Руснак // Науковий вісник Київського національного лінгвістичного університету. Серія Педагогіка та психологія. - Вип. 29. - Київ: Видавничий центр КНЛУ, 2018. - С. 72-82.

6. Bartes R. Le message publicitaire / Roland Bartes //L'aventure sémiologique.Paris: Éditions du Seuil, 1985. - P. 243-248.

7. Boyer H. L'incontournable paradigme des représentations partagées dans le traitement de la compétence culturelle en français langue étrangère / Henri Boyer // Études de linguistiques appliquée. $-2001 .-\mathrm{n}^{\circ}$ 123-124. - P. 333-340.

8. Burbea G. Le défigement dans le slogan publicitaire français / Geogiana Burbea // Language and Literature - European Landmarks of Identity, Universitatea din Piteșt. - 2007. - vol. 3. - n 2. - P. 306-312.

9. Byram M., Gribkova B., Starkey H. Développer la dimension interculturelle dans l'enseignement des langues: une introduction pratique à l'usage des enseignants / M. Byram, B. Gribkova, H. Starkey. - Strasbourg, Conseil de l'Europe, 2002. - 46 p.

10. Cossette C. Degnault, P. La publicité sociale: définitions, particularités, usages / Claude Cossette et Pénélope Degnault. - Québec, Télémaquepointorg. 2001. $-144 \mathrm{p}$.

11. Porcher L. Les médias entre éducation et communication / Louis Porcher. Paris: éd. Vuibert, coéd. Clemi / INA, coll. «Comprendre les médias», 2006. - 224 p. 


\section{Rusnak Diana}

12. Puren Ch. Perspectives actionnelles et perspectives culturelles en didactique des langues: vers une perspective co-actionnelle-co-culturelle / Christian Puren // Les Langues modernes. - 2002. - Vol. 3. - Pp. 55-71.

\section{References:}

1. Misechko O.Ye. (2018). Mizhkulturna paradygma inshomovnoyi osvity: shho kryyetsya $\mathrm{v}$ detalyax? [Intercultural Paradigm of Foreign Language Education: What is Hiding Behind the Details?] Visnyk KNLU. Pedagogikataps yxologiya, vol. 29, pp. 63-71. (in Ukrainian)

2. Elyzarova G.V. (2001). Formyrovanye mezhkulturnoj kompetencyy studentov v processe obuchenyya ynoyazychnomu obshhenyyu: Diss. dokt. ped. nauk [Developping of student"s intercultural competence in process of foreign language teaching. Dr. ped. sci. diss.]. Saint Petersburg, 371 s. (in Russian)

3. Rusnak, D.A. (2017). Mobil'nyy keys «Reklama yak zasib formuvannya mizhkul'turnoyi kompetentnosti: henderni, vikovi y etnichni stereotypy» dlya maybutnikh uchyteliv/vykladachiv frantsuz'koyi movy. Keysova $i$ podkast tekhnolohiyi formuvannya mizhkulturnoyi kompetentnosti: Kolektyvna monohrafiya. [Mobile case study for futures teachers of French: Advertising as the way of developing of intercultural competence: gender, age and national stereotypes. Case study and podcast technologies in developing of intercultural competence]. Bihych O.B. (Ed.); K.: Vyd. tsentr KNLU. Kyyiv: Editions of Kyyiv national linguistic university, pp. 22-91. (in Ukrainian)

4. Rousnak, D. (2018). Les contenus spécifiques de l'enseignement interculturel de futur senseignants de FLE: stéréotypes de genre. Visnyk KNLU. Pedagogikataps yxologiya, vol. 28, pp. 133-142.

5. Rusnak D. A. (2018) Exploiter la dimension culturelle de la publicité iconique pour l'enseignement interculturel des futurs enseignants de FLE. Visnyk KNLU. Pedagogikataps yxologiya, vol. 29, pp. 72-82.

6. Bartes R. (1985). Le message publicitaire. L'aventure sémiologique. Paris: Éditions du Seuil, pp. 243-248.

7. Boyer H. (2001). L'incontournable paradigme des représentations partagées dans le traitement de la compétence culturelle en français langue étrangère. Études de linguistiques appliquées, no 123-124, pp. 333-340.

8. Burbea G. (2007). Le défigement dans le slogan publicitaire français, Language and Literature - European Landmarks of Identity, Universitatea din Pitești, vol. 3, no 2, pp. 307-314.

9. Byram M. Gribkova B. Starkey H. (2002) Développer la dimension interculturelle dans l'enseignement des langues: une introduction pratique à l'usage des enseignants. Strasbourg, Conseil de l'Europe.

10. Cossette C., Degnault P. (2001). La publicité sociale: définitions, particularités, usages. Québec, Télémaquepointorg.

11. Porcher L. (2006). Les médias entre éducation et communication. - Paris: éd. Vuibert, coéd. Clemi/INA, coll. «Comprendre les médias».

12. Puren Ch. (2002). Perspectives actionnelles et perspectives culturelles en didactique des langues: vers une perspective co-actionnelle-co-culturell, Les Langues modernes, no 3, pp. 55-71. 